Journal Port Science Research vol:2, No:1, 2019

$\overline{\mathrm{PAPER}} \cdot$ Full original article online Free

\title{
Impact Methodology representation abstract on efficiency Iraqi pupils fifth grade and their motivation in learn fractures
}

\author{
Sahar Abbas Ibrahim \\ Directorate of Baghdad Education Karkh III, Ministry of Education, Baghdad, Iraq
}

saharabbas2010@yahoo.com

\section{أثر منهجية التمثيل المجرد على كفاءة التلاميذ \\ العراقيين للصف الخامس ودوافعهم لتعلم الكسور}

\author{
سحر عباس ابراهيم \\ وزارة التربية، مديرية تربية بغداد الكرج الثالثة، بغداد ، العراق الثرات
}

saharabbas2010@yahoo.com

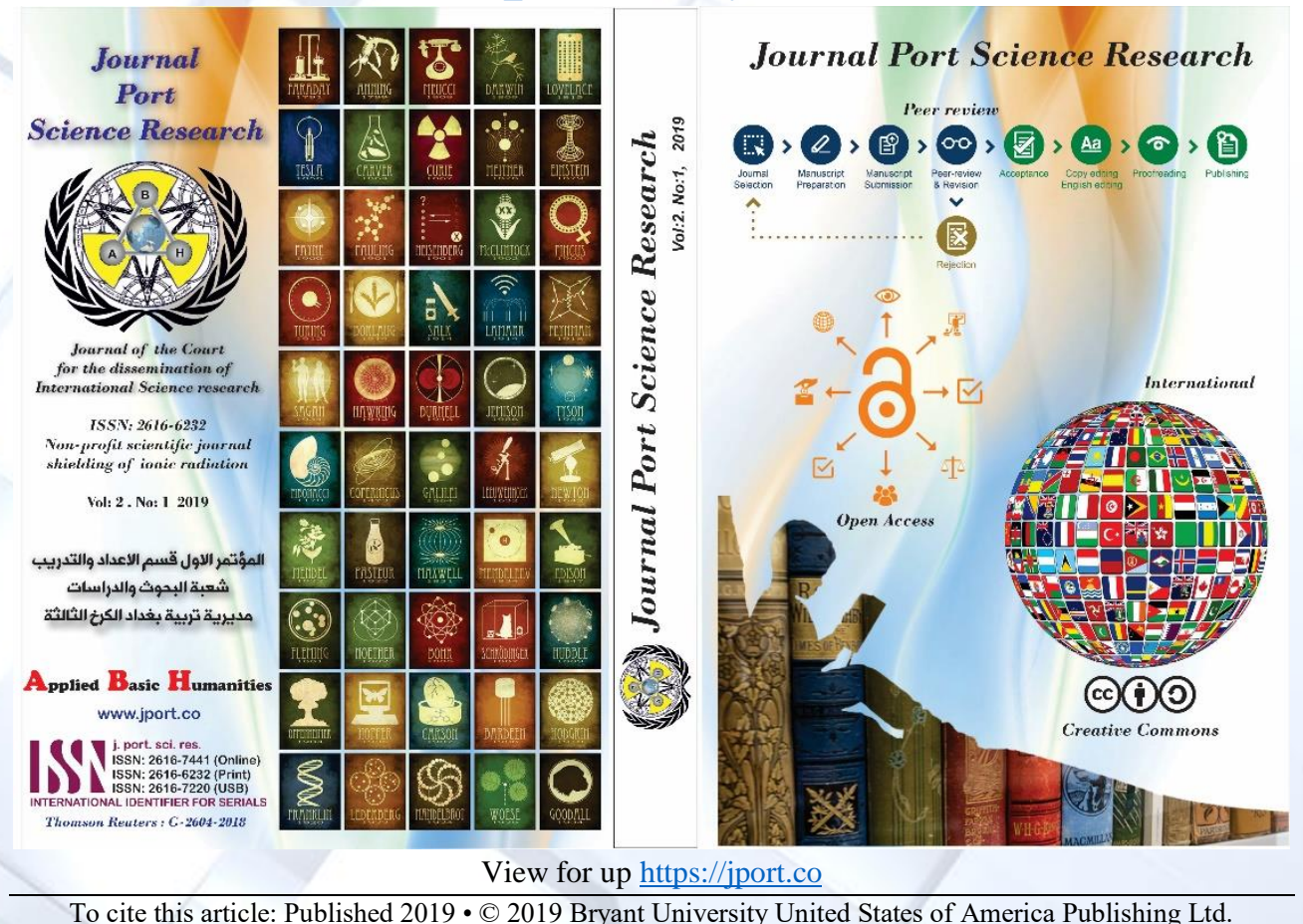


Ministry of Education Iraqi Directorate of Education Baghdad Karkh III

First Conference Department of Preparation and Training Division of Research and Studies

وزارة التريية العراقية مديرية تريية بغداد الكرخ الثالثة المؤتمر الاول قسم الاعداد والتدريب شعبة البحوث والثلراسات

\title{
Impact Methodology representation abstract on efficiency Iraqi pupils fifth grade and their motivation in learn fractures
}

\author{
Sahar Abbas Ibrahim \\ Directorate of Baghdad Education Karkh III, Ministry of Education, Baghdad, Iraq \\ saharabbas2010@yahoo.com
}

\begin{abstract}
Iraqi grade five pupils often lack proficiency in fractions and lack motivation in learning fractions through the conventional method of teaching. Research has shown that the concrete-representational-abstract (CRA) module helps primary pupils to learn fractions and give them better motivation to learn fractions. The study employed a quasi-experimental research design and two intact grade five classes from an Iraqi school in KL, Malaysia were randomly assigned to the experimental group and control group respectively. The results showed that there was a significant difference in proficiency in fractions and motivation in learning fractions between the groups and favoring the CRA module.
\end{abstract}

Keywords: CRA module, proficiency in fractions, motivation in learning fractions, primary pupils.

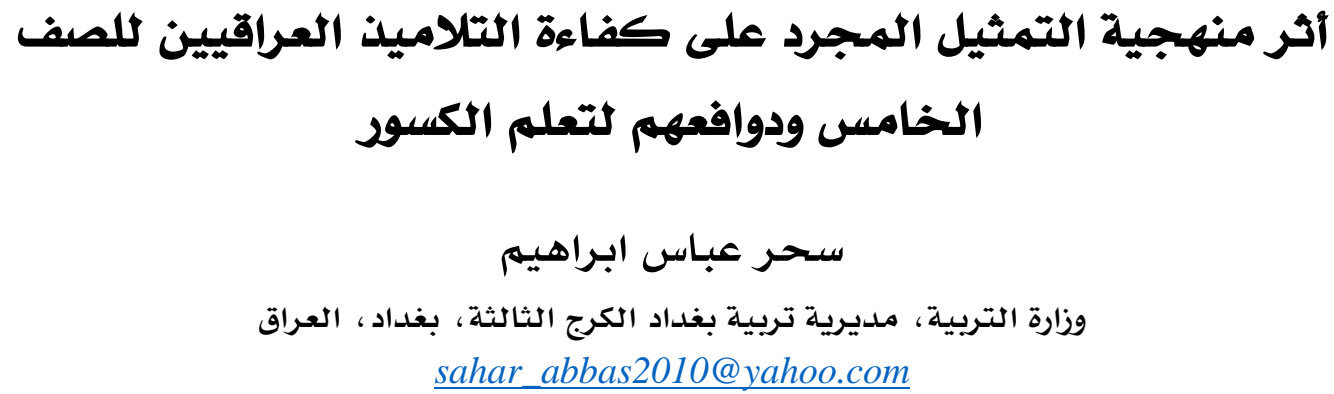

المستخلص يفتقر تلاميذ الصف الخامس افي العراق في كثير من الأحيان إلى الكفاءة في الكسور ويفتقرون إلى الدافع في تعلهم الكسور من خلال الطريقة التقليدية للتدريس. ولقد أظهرت الأبحاث أن منهج التمثيل التجريدي الهحسوس (CRA) يساعد التلاميذ في المدارس الابتدائية على تعلهم الكسور

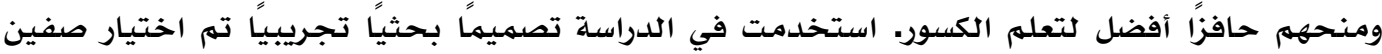
دراسيين من الصف الخامس من مدرسسة عراقية في كوالالمبور، ماليزيا بشكل عشوائي على الهمجموعة التجريبية والمـجموعة الضابطة على التوالي. أظهرت النتائج أنه كان هناك اختلاف كبير في الكفاءة

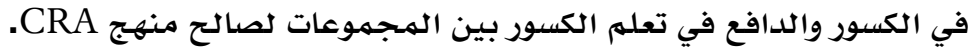

الكلهات اللالكة: منهج CRA، ، الكفاءة في الكسور، الدافع في تعله الكسور، تلاميذ الهرحلة الابتدائية. Ibrahim, S. (2019). Impact Methodology representation abstract on efficiency Iraqi pupils fifth grade and their motivation in learn fractures. Journal Port Science Research, 2(1), 137-148. 


\section{Introduction}

The knowledge of fractions is important to pupils' future success. In fact, it is necessary to learn fractions because before primary pupils proceed to decimal numbers (including measurement) with understanding, they need a deep understanding of the concept of fractions [1]. According to Charalambous and Pastaza (2005) [2], fraction is the most complex concept among children in primary education. Many studies show that pupils have problems in learning fractions and the problems persist into their adulthood [3] because of the conventional method of teaching fractions. The conventional method of teaching fractions focuses on rules and the procedural computation. Consequently, primary pupils face difficulties in learning fractions because it seems to be a complex and abstract concept and skill. Meanwhile, the National Council of Teachers of Mathematics (NCTM) [4] clearly point out that pupils in primary schools need to acquire a deep understanding of fractions and to be able to use them proficiently in solving problems such as addition and subtraction of fractions. Therefore, many efforts have been made to explore alternative ways of teaching fractions such as teaching using the ConcreteRepresentational-Abstract module which not only make students understand fractions but also at the same time can capture their attention to the lesson that is being taught. The study of Wetzel et al. [5] supported the effectiveness of teaching mathematics using the Concrete-Representational-Abstract (CRA) module .In addition, the bad situation in Iraq has resulted in the decline of the quality of education because of the on-going war [6]. As a result, Iraq did not participate in any international comparative studies such as the Trends in International Mathematics and Science Study (TIMSS) and Programmed for International Students Assessment (PISA) to help the pupils to improve their proficiency in mathematics in general and in fractions .

According to Banda, Matusz Ny, and Therrien [7], "Increasing pupils' motivation is a complex and ongoing process, especially for pupils who have often experienced extensive failure with mathematics in the past" (p.146). School professionals are constantly investigating methods to improve pupils' motivation and help pupils to be successful in school. Mwangi and McCaslin [8] point out that motivation is a psychological process that gives purpose, direction and intensity to behavior and that it is mainly responsible for differential work output. Individuals with intrinsic motivation respond to internal needs such as personal interest in a subject, satisfaction or enjoyment in a learning task that is inherently interesting while those with extrinsic motivation respond to external rewards. Such rewards include a teacher's praise and approval of their participation in a lesson, encouragement and positive feedback on task performance. The four dimensions of motivation to learn [9],[10] that are the focus of this study are interest, relevance, perceived probability of success, expectancy of success or confidence, and satisfaction. Interest arouses a learner's curiosity to learn, respond and attend to subject matter, while relevance is the extent to which learners perceive subject matter content to be significant and valuable to them . Research-based studies show that pupils who use concrete

ابراهيه، سحر عباس. (2019). أثر منهجية التمثيل المجرد على كفاءة التلاميذ العراقيين للصف الخامس ودوافعهم لتعلم

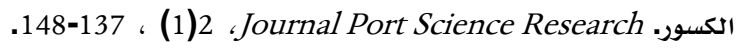


materials develop more precise and more comprehensive mental representations, often show more on-task behaviour, understand mathematical ideas, and better apply these ideas to life situations.[11]

\section{- OBJECTIVES OF THE STUDY}

The objectives of this study are as follows:

1) To determine whether there is a significant difference in proficiency in fractions between grade five pupils who learned fractions through the CRA module and grade five pupils who learned fractions through the conventional method.

2) To determine whether there is a significant difference in motivation in learning fractions between grade five pupils who learned fractions through the CRA module and grade five pupils who learned fractions through the conventional method.

\section{- RESEARCH QUESTIONS}

Specifically, this study aimed to answer the following research questions:

1) Is there a significant difference in proficiency in fractions between grade five pupils who learned fractions through the CRA module and grade five pupils who learned fractions through the conventional method?

2) Is there a significant difference in motivation in learning fractions between grade five pupils who learned fractions through the CRA module and grade five pupils who learned fractions through the conventional method?

\section{- HYPOTHESES}

The null hypotheses of this study are as follows:

1) There is no significant difference in proficiency in fractions between grade five pupils who learned fractions through the CRA module and grade five pupils who learned fractions through the conventional method.

2) There is no significant difference in motivation in learning fractions between grade five pupils who learned fractions through the CRA module and grade five pupils who learned fractions through the conventional method.

\section{METHODOLOGY}

This study employed a quasi-experimental research design namely the nonequivalent control group research design to achieve the two objectives of the study. The non-equivalent control group was used because it was difficult to randomly assign individual pupils to treatments and the treatment could be assigned in an organized manner to allow a valid statistical analysis to be carried out on the resulting data, and it could also reduce the variability.[12] In this study, the pupils were divided into two groups: (1) the control group in which the conventional method was implemented, and (2) the experimental group in which the CRA module was implemented. The population of this study consisted of the pupils in the Iraqi primary school in Kuala Lumpur, Malaysia. The two grade five classes (64 pupils) in the school were selected as the sample of the study. Each class was Ibrahim, S. (2019). Impact Methodology representation abstract on efficiency Iraqi pupils fifth grade and their motivation in learn fractures. Journal Port Science Research, 2(1), 137-148. 
randomly assigned to the experimental group (34 pupils) and control group (30 pupils). Most of the pupils had similar socioeconomic background and academic performance and their parents were studying postgraduate programs in Malaysian universities. Two teachers were selected from the school based on their field of specialization and teaching experiences. Table 1 below shows that there were 30 grade five pupils (14 boys and 16 girls) in the control group while there were 34 grade five pupils (16 boys and 18 girls) in the experimental group.

Table 1. Number of pupils in the control and experimental groups

\begin{tabular}{|c|c|c|c|c|}
\hline \multirow{2}{*}{ Group } & \multirow{2}{*}{ Teaching Method } & \multicolumn{2}{|c|}{ Number of Pupils } & \multirow{2}{*}{ Total } \\
\cline { 3 - 4 } & & Boy & Girl & \\
\hline Control & Conventional & 14 & 16 & 30 \\
\hline Experimental & CRA Module & 16 & 18 & 34 \\
\hline \multicolumn{2}{|c|}{ Total } & 30 & 34 & 64 \\
\hline
\end{tabular}

To answer the first research question of this study, two parallel Proficiency in Fractions tests namely the pre-test and post-test were used to assess the pupils' proficiency in fractions before and after the intervention respectively. The items of the Proficiency in Fractions test assessed the five strands of proficiency in fractions namely conceptual understanding, procedural fluency, strategic competence, adaptive reasoning, and productive disposition. The test items were developed by the researchers based on the Mathematical Proficiency Framework [13], as well as the standards of mathematics in the Iraqi national curriculum of mathematics for Grade five and the Iraqi Mathematics Year 5 textbook in primary schools. The Proficiency in Fractions Test has 25 items (5 items are related to conceptual understanding, 5 items are related to procedural fluency, 5 items are related to strategic competence, 5 items are related to adaptive reasoning and 5 items are related to productive disposition). The 25 items involved five topics of fractions: Equivalent fractions, Mixed numbers, convert improper fractions to mixed numbers and vice versa, Simplifying fractions, comparing fractions and Order the fractions. To answer the second research question of this study, two parallel Motivation in Learning Fractions survey namely the pre-survey and post-survey were used to assess the pupils' motivation in learning fractions before and after the intervention respectively. The items of the Motivation in Learning Fractions Survey measured the four dimensions of motivation namely Interest in learning fractions (items 1, 2, 3 and 4), Perceived probability of success items (5, 6, 7, 8, 9, 10, 11, 12, 13 and 14), Satisfaction items (15, 16, 17, 18, 19 and 20), Relevance items (21, 22, 23, 24, 25, 26 and 27). The scores in this instrument consist of 5 marks for "Strongly Agree", 4 marks for "Agree", 3 marks for "Undecided", 2 marks for "Disagree" and 1 mark for "Strongly Disagree" [14]. The first author conducted a workshop in the Iraqi school to train the grade five mathematics' teacher in the experimental group to teach the five topics of fractions using the CRA module. After the workshop, a pretest and a pre-survey were administered to the grade five pupils in both the experimental and control groups using the Proficiency in Fractions Test and Motivation in Learning Fractions Survey. After that, the experimental group

ابراهيم، سحر عباس. (2019). أثر منهجية التمثيل المجرد على كفاءة التلاميذ العراقيين للصف الخامس ودوافعهم لتعلم

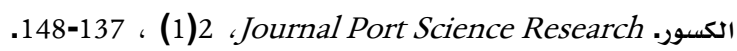


learned the five topics of fractions using the CRA module which contained lesson plans modified from the grade five mathematics textbook based on Bruner's theory [15] while the control group learned the five topics of fractions through the conventional method based on grade five mathematics textbook for about two weeks. At the end of the intervention, a post-test and post-survey were administered to the grade five pupils in both the experimental and control groups using the parallel form of the Proficiency in Fractions Test and the parallel form of the Motivation in Learning Fractions Survey.

\section{RESULTS}

The results are presented according to the two research questions of this study as follows: 6.1. Is there a significant difference in proficiency in fractions between grade five pupils who learned fractions through the CRA module and grade five pupils who learned fractions through the conventional method? Table 2 shows the mean and standard deviation of the pretest and posttest scores of the five strands of proficiency in fractions and the overall proficiency in fractions for the control and experimental group pupils respectively.

Table 2. Mean and Standard Deviation of the pretest and posttest scores of the control and experimental group pupils.

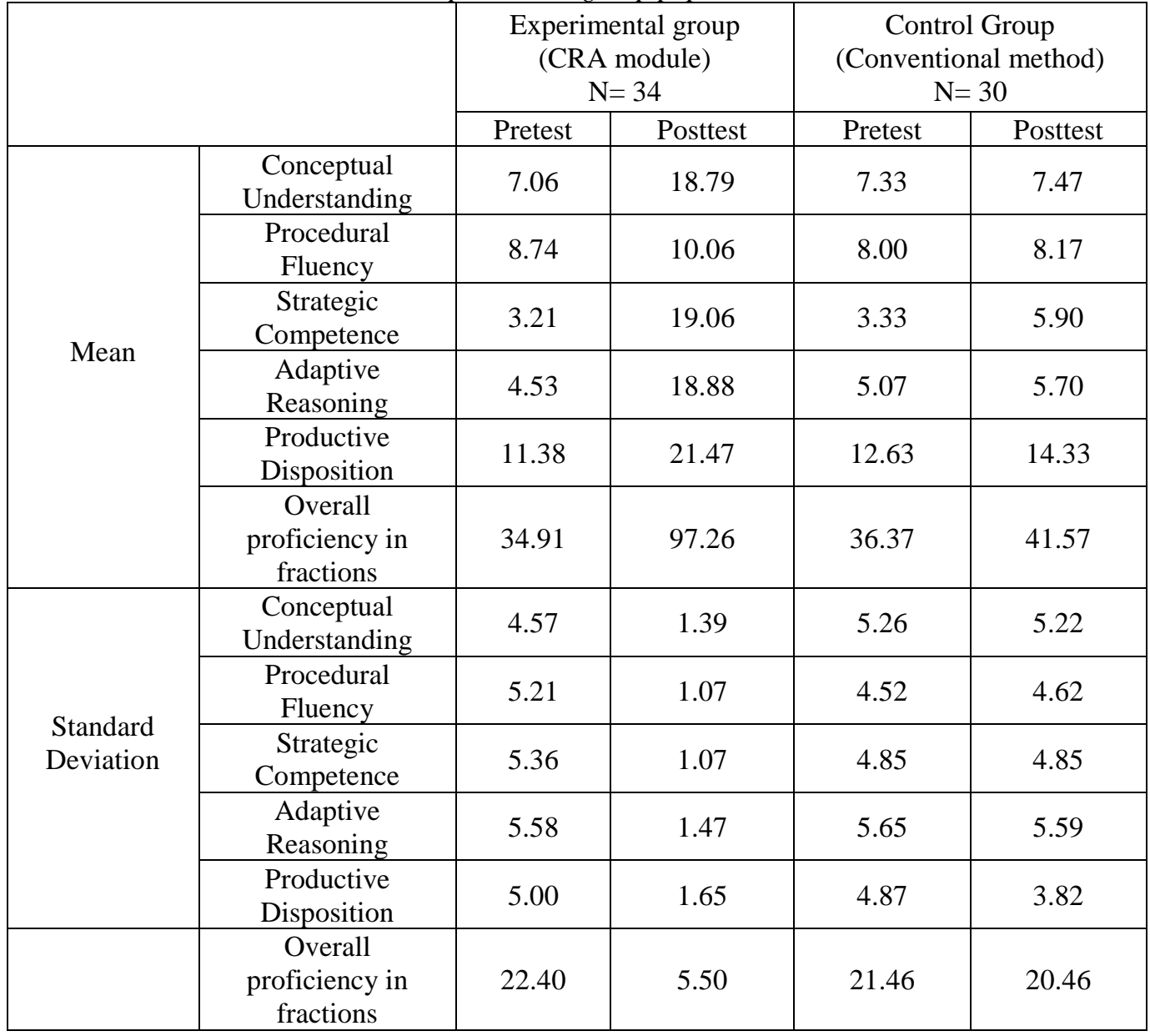

Ibrahim, S. (2019). Impact Methodology representation abstract on efficiency Iraqi pupils fifth grade and their motivation in learn fractures. Journal Port Science Research, 2(1), 137-148. 
From Table 2, the mean and standard deviation of the pretest scores of the five strands of proficiency in fractions and the overall proficiency in fractions for the experimental group and control group did not differ much. In the experimental group, the mean and standard deviation for conceptual understanding were $(\mathrm{M}=7.06$, S.D. $=4.57)$, for procedural fluency were $(\mathrm{M}=8.74$, S.D.= 5.21), for strategic competence were $(\mathrm{M}=3.21$, S.D.= 5.36), for adaptive reasoning were $(\mathrm{M}=4.53$, S.D. $=5.58)$, for productive disposition were $(\mathrm{M}=11.38$, S.D. $=5.00)$, and for the overall proficiency in fractions were $(M=34.91$, S.D. $=22.40)$. Meanwhile the mean and standard deviation of the pretest scores of the control group for conceptual understanding were $(M=7.33$, S.D. $=5.26)$, for procedural fluency were $(\mathrm{M}=8.00$, S.D.= 4.52), for strategic competence were $(\mathrm{M}=3.33$, S.D.= 4.85), for adaptive reasoning were $(\mathrm{M}=5.07, \mathrm{~S} . \mathrm{D} .=5.65)$, for productive disposition were $(\mathrm{M}=12.63$, S.D. $=4.87)$, and for the overall proficiency in fractions were $(M=36.37$, S.D. $=21.46$ ).

The posttest means scores of the experimental and control groups showed an increase compared to the pretest mean scores of the experimental and control groups. More specifically, the mean and standard deviation of the posttest scores of the experimental group for conceptual understanding were $(\mathrm{M}=18.79$, S.D.=1.39), for procedural fluency were $(M=10.06$, S.D.=1.07), for strategic competence were $(\mathrm{M}=19.06, \mathrm{~S} . \mathrm{D} .=1.07)$, for adaptive reasoning were $(\mathrm{M}=18.88$, S.D.= 1.47), for productive disposition were $(\mathrm{M}=21.47$, S.D.= 1.65), and for the overall proficiency in fractions were $(M=97.26, S . D .=5.50)$. The mean and standard deviation of the posttest scores of the control group for conceptual understanding were $(M=7.47$, S.D.= 5.22), for procedural fluency were $(M=8.17$, S.D.= 4.62), for strategic competence were $(M=5.90$, S.D.= 4.85), for adaptive reasoning were $(M=5.70$, S.D.= 5.59), for productive disposition were $(M=14.33$, S.D.=3.82), and for the overall proficiency in fractions were $(\mathrm{M}=41.57$, S.D.= 20.46). Table 3 shows the results of the independent-samples t-tests for the pretest scores of the five strands of proficiency in fractions and the overall proficiency in fractions.

Table 3. Results of the Independent-Samples t-tests for the Pre-test Scores

\begin{tabular}{|c|c|c|c|}
\hline \multirow{2}{*}{ Strands of Proficiency } & \multicolumn{2}{|c|}{$\mathrm{t}$ - tests } & \\
\cline { 2 - 4 } & $\mathrm{t}$ & $\mathrm{df}$ & $\mathrm{sig}$ \\
\hline $\begin{array}{c}\text { Conceptual } \\
\text { understanding }\end{array}$ & -0.22 & 62 & 0.82 \\
\hline Procedural fluency & -0.60 & 62 & 0.55 \\
\hline Strategic competence & -0.10 & 62 & 0.92 \\
\hline Adaptive reasoning & -0.38 & 62 & 0.70 \\
\hline Productive disposition & -1.01 & 62 & 0.32 \\
\hline $\begin{array}{c}\text { Overall Proficiency in } \\
\text { fractions }\end{array}$ & -0.26 & 62 & 0.79 \\
\hline
\end{tabular}

As shown in Table 3, all the $p$-values of the independent-samples $t$-tests are greater than 0.05 . Thus, the null hypotheses failed to be rejected for all the five strands of proficiency of fractions and the overall proficiency in fractions.

ابراهيم، سحر عباس. (2019). أثر منهجية التمثيل المجرد على كفاءة التلاميذ العراقيين للصف الخامس ودوافعهم لتعلم

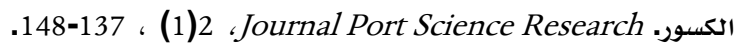


Thus, it can be concluded that there is no significant difference in all the five strands of proficiency of fractions and the overall proficiency in fractions between grade five pupils who learned fractions through the CRA module and grade five pupils who learned fractions through the conventional method before the start of the intervention. Therefore, the independent-samples $t$-tests were used for the post-test scores of the five strands of proficiency in fractions and the overall proficiency in fractions to answer the first research question.

Table 4 shows the results of the independent-samples $t$-tests for the post-test scores of the five strands of proficiency in fractions and the overall proficiency in fractions. As shown in Table 4, all the $p$-values of the independent-samples $t$-tests are less than 0.05 .

Thus, the null hypotheses were rejected for all the five strands of proficiency of fractions and the overall proficiency in fractions. Therefore, it can be concluded that there is a significant difference in all the five strands of proficiency in fractions and the overall proficiency in fractions between grade five pupils who learned fractions through the CRA module and grade five pupils who learned fractions through the conventional method after the intervention.

Table 4. Results of the Independent-Samples $t$ - tests for the post-test scores

\begin{tabular}{|c|c|c|c|}
\hline \multirow{2}{*}{ Strands of Proficiency } & \multicolumn{2}{|c|}{$\mathrm{t}$ - tests } & sig \\
\cline { 2 - 4 } & $\mathrm{t}$ & 32.61 & 0.00 \\
\hline $\begin{array}{c}\text { Conceptual } \\
\text { understanding }\end{array}$ & 11.52 & 31.75 & 0.00 \\
\hline Procedural fluency & 12.60 & 31.50 & 0.00 \\
\hline Strategic competence & 14.54 & 32.55 & 0.00 \\
\hline Adaptive reasoning & 12.54 & 38.29 & 0.00 \\
\hline Productive disposition & 9.50 & 32.70 & 0.00 \\
\hline $\begin{array}{c}\text { Overall proficiency in } \\
\text { fractions }\end{array}$ & 14.45 & & \\
\hline
\end{tabular}

6.2. Is there a significant difference in motivation in learning fractions between grade five pupils who learned fractions through the CRA module and grade five pupils who learned fractions through the conventional method?

Table 5 shows the mean and standard deviation of the pre-survey and post-survey scores of the four dimensions of motivation in learning fractions and the overall motivation in learning fractions for the control and experimental group pupils respectively. 
Journal port Science Research Available online www.jport.co Volume: 2, No:1

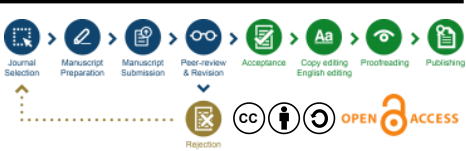

Table 5. Mean and Standard Deviation of the pre-survey and post-survey scores of the control and experimental group pupils

\begin{tabular}{|c|c|c|c|c|c|}
\hline & \multicolumn{2}{|c|}{$\begin{array}{l}\text { Experimental group } \\
\text { (CRA module) } \\
\mathrm{N}=34\end{array}$} & \multicolumn{2}{|c|}{$\begin{array}{c}\text { Control Group } \\
\text { (Conventional method) } \\
\mathrm{N}=30\end{array}$} \\
\hline & & $\begin{array}{c}\text { Pre- } \\
\text { survey }\end{array}$ & Post-survey & Pre-survey & Post-survey \\
\hline \multirow{5}{*}{ Mean } & Satisfaction & 18.71 & 22.65 & 15.90 & 16.17 \\
\hline & Relevance & 21.32 & 24.79 & 18.70 & 19.10 \\
\hline & $\begin{array}{c}\text { Perceived Probability } \\
\text { of success }\end{array}$ & 30.18 & 36.76 & 26.53 & 26.90 \\
\hline & $\begin{array}{l}\text { Interest of Learning } \\
\text { fractions }\end{array}$ & 12.53 & 14.94 & 10.80 & 10.67 \\
\hline & $\begin{array}{l}\text { Motivation in learning } \\
\text { fractions }\end{array}$ & 82.74 & 99.15 & 71.40 & 72.83 \\
\hline \multirow{5}{*}{$\begin{array}{l}\text { Standard } \\
\text { Deviation }\end{array}$} & Satisfaction & 5.33 & 2.04 & 6.89 & 6.85 \\
\hline & Relevance & 6.08 & 2.45 & 8.46 & 8.54 \\
\hline & $\begin{array}{c}\text { Perceived Probability } \\
\text { of success }\end{array}$ & 6.86 & 4.35 & 10.00 & 11.12 \\
\hline & $\begin{array}{l}\text { Interest of Learning } \\
\text { fractions }\end{array}$ & 3.99 & 2.32 & 5.04 & 4.08 \\
\hline & $\begin{array}{l}\text { Motivation in learning } \\
\text { fractions }\end{array}$ & 19.73 & 8.98 & 29.24 & 29.39 \\
\hline
\end{tabular}

From Table 5, the mean and standard deviation of the pre-survey scores of the four dimensions of motivation in learning fractions and the overall motivation in learning fractions for the experimental and control groups did not differ much. The mean and standard deviation of the pre-survey scores of the experimental group for Satisfaction were $(M=18.71$, S.D.= 5.33), for Relevance were $(M=21.32$, S.D.= 6.07), for Perceived Probability of success were $(M=30.18$, S.D.=6.86), for Interest of Learning fractions were $(M=12.53$, S.D.=3.99), and for the overall motivation in learning fractions were $(M=82.74$, S.D.= 19.73). Meanwhile the mean and standard deviation of the pre-survey scores of the control group for Satisfaction were $(M=15.90$, S.D.= 6.89), for Relevance were $(M=18.70$, S.D.= 8.46), for Perceived Probability of Success were $(M=26.53$, S.D. $=10.00)$, for Interest of Learning fractions were $(M=10.67, S . D .=5.04)$, and for the overall motivation in learning fractions of the control group were $(\mathrm{M}=71.40$, S.D. $=29.24)$.

The post-survey means scores of the experimental and control groups showed an increase compared to the pre-survey mean scores of the experimental and control groups. More specifically, the mean and standard deviation of the post-survey scores of the experimental group for Satisfaction were $(M=22.65$, S.D.=2.04), for Relevance were $(M=24.79$, S.D.=2.45), for Perceived Probability of Success were $(M=36.76$, S.D. $=4.35)$, for Interest of Learning fractions were $(M=14.94$, S.D.= 2.32), and for the overall motivation in learning fractions of the experimental group were $(M=99.15$, S.D. $=8.98)$ and the post-survey score of the control group for

ابراهيه، سحر عباس. (2019). أثر منهجية التمثيل المجرد على كفاءة التلاميذ العراقيين للصف الخامس ودوافعهم لتعلم

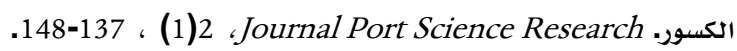


Satisfaction were $(M=16.17$, S.D.= 6.86), for Relevance were $(M=19.10$, S.D. $=$ 8.54), for Perceived Probability of success were $(M=26.90$, S.D.= 11.12), for Interest of Learning fractions were $(M=10.67$, S.D.= 4.08), and for the overall motivation in learning fractions of the control group were $(M=72.83$, S.D.=29.39).

Table 6 shows the results of the independent-samples t-tests for the pre-survey scores of the four dimensions of motivation in learning fractions and the overall motivation in learning fractions.

Table 6. Results of the Independent-Samples $t$ - tests for the pre-survey

\begin{tabular}{|c|c|c|c|}
\hline \multirow{2}{*}{ Items } & \multicolumn{2}{|c|}{$\mathrm{t}$ - tests } & \\
\cline { 2 - 4 } & $\mathrm{t}$ & $\mathrm{df}$ & $\mathrm{sig}$ \\
\hline Satisfaction & 1.83 & 62 & 0.07 \\
\hline Relevance & 1.73 & 62 & 0.09 \\
\hline $\begin{array}{c}\text { Perceived probability of } \\
\text { success }\end{array}$ & 1.72 & 62 & 0.09 \\
\hline Interest of learning fraction & 1.53 & 62 & 0.13 \\
\hline $\begin{array}{c}\text { Overall Motivation in learning } \\
\text { fractions }\end{array}$ & 1.84 & 62 & 0.07 \\
\hline
\end{tabular}

As shown in Table 6, all the $p$-values of the independent-samples $t$-tests are greater than 0.05 . Thus, the null hypotheses failed to be rejected for all the four dimensions of motivation and the overall motivation in learning fractions. Thus, it can be concluded that there is no significant difference in the mean score of the four dimensions of motivation and the overall motivation in learning fractions between the experimental and control groups before the start of the intervention. Hence, the independent-samples t-test can be used to determine if there is a significant difference in the mean score of the post-survey of the four dimensions of motivation in learning fractions and the overall motivation in learning fractions between the experimental and control groups.

Table 7 shows the results of the independent-samples $t$-tests for the post-surveys scores of the four dimensions of motivation in learning fractions and the overall motivation in learning fractions. As shown in Table 7, all the p-values of the independent-samples t-test are less than 0.05 . Thus, the null hypotheses are rejected for all the four dimensions of motivation and the overall motivation in learning fractions. Thus, it can be concluded that there is a significant difference in motivation in learning fractions between grade five pupils who learned fractions through the CRA module and grade five pupils who learned fractions through the conventional method. 


\section{Journal port Science Research Available online www.jport.co Volume: 2, No:1}

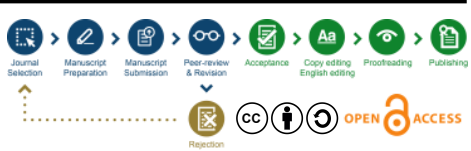

Table 7. Results of the Independent-Samples t- tests for the post-survey

\begin{tabular}{|c|c|c|c|}
\hline \multirow{2}{*}{ Items } & \multicolumn{2}{|c|}{$\mathrm{t}$ - tests } & \\
\cline { 2 - 4 } & $\mathrm{t}$ & $\mathrm{df}$ & $\mathrm{sig}$ \\
\hline Satisfaction & 4.99 & 33.55 & 0.00 \\
\hline Relevance & 3.53 & 33.21 & 0.00 \\
\hline Perceived probability of success & 4.56 & 36.77 & 0.00 \\
\hline Interest of learning fraction & 5.06 & 44.73 & 0.00 \\
\hline $\begin{array}{c}\text { Overall Motivation in learning } \\
\text { fractions }\end{array}$ & 4.71 & 33.77 & 0.00 \\
\hline
\end{tabular}

\section{DISCUSSION AND CONCLUSION}

In this study, the CRA module involved the fundamentals of fractions such as equivalent fractions, fractional numbers, converting fractions to fractional numbers, converting fractional numbers to fractions, simplifying fractions, comparing fractions and order fractions. The results indicated that the implementation of CRA module in teaching the topics of fractions had increased pupils' proficiency in fractions and there was a significant effect of the CRA module on the experimental group pupils' proficiency in fractions compared to the control group pupils who learned fractions using the conventional method. Besides that, it was also found that the CRA module had a significant effect on the experimental group pupils' motivation in learning fractions compared to the control group pupils. According to Bruner's (1966) theory, the CRA module required the pupils to draw and represent the abstract fraction concepts because their learning began with actions such as touching, feeling and manipulating based on the concrete form so that they could understand better. For the first research question, the comparison between the mean scores for the post-test of the experimental and control groups showed that the mean score for the post-test of the experimental group in conceptual understanding $(M=18.79)$ was higher than the mean score for post-test of the control group ( $\mathrm{M}=7.47)$, the mean score for the post-test of the experimental group in procedural fluency $(\mathrm{M}=10.06)$ was higher than the mean score for post-test of the control group ( $M=8.17)$, the mean score for the post-test of the experimental group in strategic competence $(\mathrm{M}=19.06)$ was higher than the mean score for posttest of the control group $(M=5.90)$, the mean score for the post-test of the experimental group in adaptive reasoning $(\mathrm{M}=18.88)$ was higher than the mean score for post-test of the control group ( $M=5.70)$, the mean score for the post-test of the experimental group in productive disposition $(\mathrm{M}=21.47)$ was higher than the mean score for post-test of the control group $(\mathrm{M}=14.33)$, and the mean score for the post-test of the experimental group in overall proficiency in fractions $(M=97.26)$ was higher than the mean score for post-test of the control group $(\mathrm{M}=41.57)$.

Meanwhile for the second research question, the comparison between the mean scores for the post-survey of the experimental and control groups, it showed that the mean score for the post-survey in Satisfaction $(M=22.65)$ was higher than the

ابراهيه، سحر عباس. (2019). أثر منهجية التمثيل المجرد على كفاءة التلاميذ العراقيين للصف الخامس ودوافعهم لتعلم

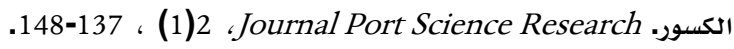


mean score for post- survey of the control group $(M=16.17)$, the mean score for the post- survey of the experimental group in relevance $(M=24.79)$ was higher than the mean score for post- survey of the control group $(M=19.10)$, the mean score for the post- survey of the experimental group in perceived probability of success $(M=36.76)$ was higher than the mean score for post- survey of the control group $(M=26.90)$, the mean score for the post-survey of the experimental group in interest learning fractions $(\mathrm{M}=14.94)$ was higher than the mean score for post-survey of the control group $(\mathrm{M}=10.67)$, the mean score for the post-survey of the experimental group in overall motivation in learning fractions $(M=99.15)$ was higher than the mean score for post-survey of the control group $(M=72.83)$. This indicates that the CRA module worked better than the other the conventional method in teaching the topics of fractions because it enhanced pupils' conceptual understanding (Serpil et al., 2005) through drawing and representing the fractions into visual forms which made them understand better the concept of fractions. In addition, it could help the teachers to turn the passive mode of pupils at the beginning of the lesson into active mode and increased their participation despite the short lesson time and the abstract fraction concepts in mathematics textbook.

\section{References}

[1] Baturo, Annette R. \& Cooper, Tom. (2008). Developing mathematics understanding through cognitive diagnostic assessment tasks. Department of Education, Employment and Workplace Relations, Canberra, A.C.T.

[2] Charalambous, C. Y., \& Pitta-Pantazi, D. (2005). Revisiting a Theoretical Model on Fractions: Implications for Teaching and Research. Proceedings of the 29th Conference of the International Group for the Psychology of Mathematics Education, 2(1983), 233-240.

[3] Bruce, C. D., \& Ross, J. (2009). Conditions for Effective Use of Interactive On-line Learning Objects: The case of a fraction's computer- based learning sequence. The Electronic Journal of Mathematics and Technology, 3(1), 13-29.

[4] National Council of Teachers of Mathematics. (2012). Error patterns in solving fraction computation problems among struggling sixth grade students. Retrieved March, 2019, from https://nctm.confex.com/nctm/2012RP/webprogram/Session10319.html

[5] Witzel, B. S., Mercer, C. D., \& Miller, M. D. (2003). Teaching Algebra to Students with Learning Difficulties: An Investigation of an Explicit Instruction Model. Learning Disabilities Research and Practice, 18(2), 121-131. https://doi.org/10.1111/1540$\underline{5826.00068}$

[6] UNESCO, (2003). Situation Analysis of Education in Iraq.p.56. Retrieved March, 2019, from https://unesdoc.unesco.org/ark:/48223/pf0000130838

Ibrahim, S. (2019). Impact Methodology representation abstract on efficiency Iraqi pupils fifth grade and their motivation in learn fractures. Journal Port Science Research, 2(1), 137-148. 
[7] Banda, D. R., Matuszny, R. M., \& Therrien, W. J. (2009). Enhancing motivation to complete math tasks using the high-preference strategy. Intervention in School and Clinic, 44(3), 146-150. https://doi.org/10.1177/1053451208326052

[8] Mwangi, J. G., \& McCaslin, N. L. (1994). The motivation of Kenya's Rift Valley extension agents. Journal of Agricultural Education, 35(3), 35-43. https://pdfs.semanticscholar.org/450c/890a51daa3da57dbbabf3bdc4a354c681dde.pdf

[9] Burden, P. R. (1995). Classroom Management and Discipline: Methods To Facilitate Cooperation and Instruction. Longman Publishers USA, 10 Bank Street, White Plains, NY 10606-1951. https://eric.ed.gov/?id=ED387211

[10] Horn, I. (2005). Discourse that Promotes Mathematical Reasoning: An Analysis of an Effective Algebra Teacher. Paper presented at the annual meeting of the North American Chapter of the International Group for the Psychology of Mathematics Education, Hosted by Virginia Tech University Hotel Roanoke \& Conference Center, Roanoke,VA Online <APPLICATION/PDF>.2013-12-

17 from http://citation.allacademic.com/meta/p24748_index.html

[11] Suydam, M. N., \& Higgins, J. L. (1977). Activity-Based Learning in Elementary School Mathematics: Recommendations from Research. https://eric.ed.gov/?id=ED144840

[12] KOĞ, O. U., \& BAŞER, N. E. (2012). The Role of Visualization Approach on Students' Attitudes Towards and Achievements in Mathematics. Elementary Education Online, 11(4), 945-957. http://ilkogretim-online.org.tr/index.php/io/article/download/1457/1313

[13] Findell, B. (2002). Adding it up: Helping children learn mathematics. Book Reviews (p. 461). National Academy Press. Retrieved from ftp://129.132.148.131/EMIS/journals/ZDM/zdm026r1.pdf

[14] Githua, B. N., \& Mwangi, J. G. (2003). Students' mathematics self-concept and motivation to learn mathematics: Relationship and gender differences among Kenya's secondary-school students in Nairobi and Rift Valley provinces. International Journal of Educational Development, 23(5), 487-499. https://doi.org/10.1016/S07380593(03)00025-7

[15] Olson, D. R. (1976). Towards a theory of instructional means. Educational Psychologist, 12(1), 14-35. https://doi.org/10.1080/00461527609529153

ابراهيه، سحر عباس. (2019). أثر منهجية التمثيل المجرد على كفاءة التلاميذ العراقيين للصف الخامس ودوافعهم لتعلم

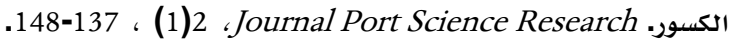

